Tyndale Bulletin 68.2 (2017) 203-222

\title{
DIAGNOSING RELIGIOUS EXPERIENCE IN ROMANS $8^{1}$
}

\author{
Mark Wreford \\ (mark.wreford@nottingham.ac.uk)
}

\begin{abstract}
Summary
In this article, I consider Paul's use of adoption language in Romans 8 and argue that religious experience played an important role in its development. By looking closely at what Paul says about adoption and life in the Spirit, I try to identify what kind of experience this language might be articulating. Further, I suggest that it is necessary to consider how biblical scholars can best ensure they take account of religious experience when performing exegesis, offering a heuristic definition of religious experience which moves beyond the language of the NT itself, but is not conceptually anachronistic, to address a lack in the literature.
\end{abstract}

\section{Introduction}

As the first section of Romans 8 reaches its climax in verses 15-16, Paul reminds his readers, 'you did not receive a spirit of slavery again

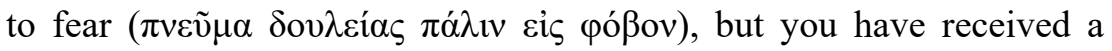

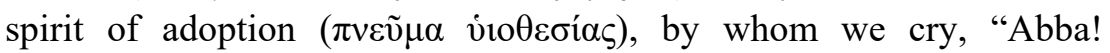
Father!" This same Spirit ( $\alpha$ v่ ò $\tau$ ò $\pi v \varepsilon \tilde{v} \mu \alpha$ ) bears witness with our spirit ( $\sigma 0 \mu \mu \alpha \rho \tau v \rho \varepsilon \tilde{\imath} \tau \tilde{\varphi} \pi v \varepsilon v ́ \mu \alpha \tau \imath \dot{\eta} \mu \tilde{\omega} v)$ that we are children of God.' This metaphor ${ }^{2}$ powerfully depicts the theological reality of the

\footnotetext{
1 An earlier draft of this article was presented as a paper at the Tyndale Fellowship Quadrennial Conference in 2016. I am grateful to those present, as well as to my reviewers and my doctoral supervisor Prof. Roland Deines, for their insightful questions and comments which have strengthened this revision. I am also grateful to Midlands3Cities DTP, who funded this research.

2 At both the oral presentation of this paper and in the reviewers' comments, the use of 'metaphor' was challenged on the basis that the change Paul depicts is ontological,
} 
believer's change of status before God - from slave under a cruel master to adopted child. However, Paul also presents the believers' cry of 'Abba! Father!' as the expressed evidence of the Spirit of adoption's internal 'witness' with their own spirit. This suggests that the Spirit of adoption communicates something which impacts the believers' understanding of their status, and which manifests itself in the cry of 'Abba! Father!' This article will explore this possibility, arguing that the language of adoption in Romans 8 is best understood as an attempt to articulate the impact of a particular religious experience $(\mathrm{RE})^{3}$ which Paul believes he and his addressees have both had, and would recognise from this description.

In suggesting that Paul's language of adoption attempts to give expression to a prior experiential reality, I am following Eduard Schweizer's claim that 'Long before the Spirit was a theme of doctrine, He was a fact in the experience of the community. ${ }^{\prime}$ In a similar manner to the way that the pneumatological reflection in the NT appears to have developed out of experiences in which the earliest believers discerned the work of God's Spirit, ${ }^{5}$ I am arguing that Paul's language of adoption can be better understood as a response to a 'question that arose' from his and his addressees' lived experience than as an abstract theological formula imposed upon it. ${ }^{6}$ If this is correct, this test case can have a wider relevance, and I will use my analysis of Paul's argument in Romans 8 to suggest a more general, heuristic definition of RE as it appears in the NT. Doing this will enable greater conceptual precision in taking account of how experience is a factor in

making the believer's adoption by God somehow 'more real' than the relationships whose terminology is used to describe it. I understand the point, and my argument does not offer a verdict either way.

3 In speaking about 'religious experience', I follow Colleen Shantz, 'Opening the Black Box: New Prospects for Analyzing Religious Experience' in Experientia II: Linking Text and Experience, ed. Colleen Shantz and Rodney A. Werline (Atlanta: SBL, 2012), 1-15 (11) in talking about 'a noun modified by an adjective' (i.e. experience whose object is religious) rather than a sui generis 'compound noun' (i.e. a distinctive kind of experience).

4 Eduard Schweizer, ' $\pi v \varepsilon \tilde{v} \mu \alpha$ ' in TDNT, 6:332-451 (396).

5 Cf. e.g. Jörg Frey, 'How Did the Spirit Become a Person?' in The Holy Spirit, Inspiration, and the Cultures of Antiquity: Multidisciplinary Perspectives, ed. Jörg Frey and John R. Levison (Ekstasis 5; Berlin: De Gruyter, 2014), 343-72. For a parallel argument regarding Christology, cf. Larry W. Hurtado, 'Religious Experience and Religious Innovation in the New Testament', Journal of Religion 80 (2000), 183-205

6 Cf. Anthony C. Thiselton, The Hermeneutics of Doctrine (Grand Rapids: Eerdmans, 2007), esp. 3-18 and 43-61; the terminology is Gadamer's. 
the development of theological thought within the NT, because whatever working definition of RE is assumed functions 'as a means of pointing to the sort of reality we mean and enabling us to distinguish among its cognates' ${ }^{7}$

In the first instance, however, I will follow Ulrich Luz's approach in his 2004 essay 'Paul as Mystic'. Luz recognises that even the label 'mystic' is anachronistic, ${ }^{8}$ so reframes the topic, considering 'the link between theology and religious experience in Paul' as a variation on the theological question of 'the relationship between the Christus pro nobis and the Christus in me'. ${ }^{9}$ Here, Christus pro nobis is concerned with ontological or theological realities before God, whereas Christus in me draws attention to the recognisable effects of God's action in this world. This is Luz's way of trying to 'point to the sort of reality we mean'. My aim in taking up this distinction is not to divide unnecessarily between theological realities and their present effects, but to raise more precisely the question of the relationship between the two in the development of Paul's thought. Specifically, I will argue that in Romans 8 the recognisable effects of God's action preceded and influenced Paul's description of theological reality, and that the language of adoption represents a fitting articulation of his and his addressees' RE.

\section{Adoption and Religious Experience}

The adoption metaphor is introduced at an important point in Paul's argument in Romans: chapter 8 concludes a long section of the letter which begins in 5:1 ${ }^{10}$ and considers the present impact of Christ's work on the believer. This is particularly the case in the first section of Romans 8: the conjunctive ö $\rho \alpha$ võv (therefore now) in 8:1 signals the

7 Luke Timothy Johnson, Religious Experience in Earliest Christianity: A Missing Dimension in New Testament Studies (Minneapolis: Fortress, 1998), 60.

8 Cf. Ulrich Luz, 'Paul as Mystic' in The Holy Spirit and Christian Origins: Essays in Honour of James D. G. Dunn, ed. Graham N. Stanton et al. (Grand Rapids: Eerdmans, 2004), 131-43.

9 Luz, 'Paul as Mystic', 134.

10 So e.g. Richard N. Longenecker, The Epistle to the Romans (NIGTC; Grand Rapids: Eerdmans, 2016); Robert Jewett, Romans (Hermeneia; Minneapolis: Fortress, 2007); Douglas Moo, The Epistle to the Romans (NICNT; Grand Rapids: Eerdmans, 1996); cf. Ulrich Wilckens, Der Brief and die Römer (EKK; Neukirchen-Vluyn: Neukirchener Verlag, 1978-1982, repr. 2010) and James D. G. Dunn, Romans 1-8 (WBC 38A; Dallas: Word, 1988) who prefer to start the section at the end of chapter 5. 
focus of verses 8:1-17 on the eschatological present, i.e. what is true for the believer right now. ${ }^{11}$ The result is what Douglas Moo calls a 'rich and comprehensive portrayal of what it means to be a Christian'12 at the heart of Paul's most theologically developed epistle. In this passage, Paul explores the way that the new theological status of 'those who are in Christ Jesus' (8:1) should have recognisable effects as they 'walk not according to the flesh but according to the Spirit' (8:4), 'set their minds on the things of the Spirit' (8:5), and 'put to death the deeds of the body' (8:13). At the climax of this passage, Paul introduces the adoption metaphor.

Paul's description of adoption focuses on one particularly 'recognisable effect' of God's action: the believers' cry of 'Abba! Father!' (8:15). According to Paul, this cry is made possible by the reception of the 'Spirit of adoption', and it is presented as the only external evidence of the theological transformation Paul describes as being adopted. The fact that Paul uses 'Abba' - an Aramaic loanword at such a critical point in his argument demonstrates that he expected his audience to recognise this language, even when it was placed on their own lips. ${ }^{13}$ This is significant, given that the term only occurs three times in the New Testament: twice in parallel accounts of adoption (Rom. 8:15; Gal. 4:6), and once in the mouth of Jesus in deep distress as he prays in Gethsemane (Mark 14:36). ${ }^{14}$ Beyond the obvious point that calling out to God as 'Abba' reflects an understanding of God as Father, ${ }^{15}$ its background and significance have been hotly contested since Joachim Jeremias' influential suggestion that Abba was

11 So, i.a. Longenecker, Romans, 684; Thomas R. Schreiner, Romans (BECNT Grand Rapids: Baker Academic, 1998), 387; John Ziesler, Paul's Letter to the Romans (London: SCM Press, 1989), 201; cf. Jewett, Romans, 474-530, who favours a cosmic reading.

12 Moo, Romans, 468.

13 See e.g. Arland J. Hultgren, Paul's Letter to the Romans (Grand Rapids: Eerdmans, 2011), 314; Gordon D. Fee, God's Empowering Presence: The Holy Spirit in the Letters of Paul (Grand Rapids: Baker Academic, 1994), 410.

14 Gottlob Schrenk, ' $\pi \alpha \tau \eta ́ \rho '$ in TDNT 5:974-1022 (984-85), sees Abba as the vorlage of every New Testament occurrence of $\pi \alpha \tau$, $\rho$, and James D. G. Dunn, Jesus and the Spirit: A Study of the Religious and Charismatic Experience of Jesus and the First Christians as Reflected in the New Testament (London: SCM, 1975), 21-24 assumes that the disciples were picking up Jesus' distinctive prayer language addressing God as 'Abba' more broadly when they called him 'Father'. However, Reinhard Feldmeier and Hermann Spieckermann, God of the Living: A Biblical Theology, trans. Mark E. Biddle (Waco: Baylor, 2011), 69 see the usage here as highly significant.

15 See below. 
an intimate form of address used by small children and uniquely appropriated by Jesus to express his relationship to God. ${ }^{16}$ Outspoken critics like James Barr have brought helpful corrective balance to Jeremias' view, ${ }^{17}$ but Gordon Fee's nuanced discussion of the possibilities still leads him to the conclusion that 'believers now, by the Spirit of the Son, are using the language of the Son ... [and that] a form of intimacy with God is involved'. ${ }^{18}$ In using Christ's language as their own, Paul's addressees were also claiming his intimate relationship with the Father for themselves.

Though the prominence of 'Father' ( $\pi \alpha \tau \eta \dot{\rho})$ terminology in Paul's greetings ${ }^{19}$ demonstrates that it was a ubiquitous form of devotional address in earliest Christianity, Paul's unusual use of 'Abba' intensifies both the intimacy and the emotion implied in the reference to God as Father here. The use of the distinctive verb $\kappa \rho \alpha ́ \zeta \omega$ (cry) points in a similar direction. The Apostle only employs this verb in the context of adoption (Rom. 8:15; Gal. 4:6) and to describe Isaiah's prophetic speech in the emotionally charged context of Romans 9:27. Its relative rarity and association with the Abba cry suggests that he is likely drawing on a recognisable and specific devotional ${ }^{20}$ practice here. Whilst it is possible to detect a reference to an ecstatic or liturgical cry, ${ }^{21}$ Barrett astutely notes that 'the contrast between a liturgical prayer and a free prayer spontaneously inspired by the Spirit may well have been less marked in the first- than in the twentieth-century mind'. ${ }^{22}$ What is certain is that the cry is presented as both intensely

16 Cf. Abba: Studien zur neutestamentlichen Theologie und Zeitgeschichte (Göttingen: Vandenhoek und Ruprecht, 1966); Joachim Jeremias, The Prayers of Jesus (London: SCM, 1967), chapter 1.

17 Cf. "“Abba" isn't "Daddy", Journal of Theological Studies 39 (1988), 28-47, and “"Abba, Father” and the familiarity of Jesus' Speech', Theology 91 (1988), 173-79.

18 Fee, Empowering Presence, 411-12 (italics original). Cf. also Schrenk, ' $\pi \alpha \tau \eta \dot{\rho} \rho$ ', 984-85.

19 Rom. 1:7; 1 Cor. 1:3; 2 Cor. 1:2-3; Gal. 1:1; Eph. 1:2; Phil. 1:2; Col. 1:2; 1 Thess. 1:1, 3; 2 Thess. 1:1-2; 1 Tim. 1:2; 2 Tim. 1:2; Titus 1:4; Phlm. 3.

20 Larry W. Hurtado, Lord Jesus Christ: Devotion to Jesus in Earliest Christianity (Grand Rapids: Eerdmans, 2003), 3 defines 'devotion' as a 'portmanteau word for the beliefs and related religious actions that constituted the expressions of religious reverence of early Christians'. This is the sense in which I intend it here.

21 Ernst Käsemann, Commentary on Romans, trans. Geoffrey W. Bromiley (London: SCM, 1970), 227 suggests an ecstatic and liturgical cry on the basis of the plural. Dunn, Romans, 453; Moo, Romans, 502 n.34; and Jewett, Romans, 498 follow him.

22 C. K. Barrett, A Commentary on the Epistle to the Romans (BNTC; London: A. \& C. Black, 1957), 163-64. 
emotional and familiar. However, it is most likely that the Apostle is referring here to an expression of deeply felt prayer; both the example

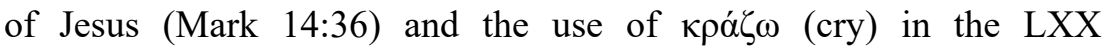
translation of the Psalms point in this direction. ${ }^{23}$ Accordingly, it appears that at intensely emotional moments of prayer, Paul's addressees called out to God as Abba under the inspiration of the Spirit - possibly consciously following the example of Jesus in Mark 14:36 ${ }^{24}$ - and he uses this as evidence of their adoption. In this way, Paul's depiction of the Abba cry does not suggest a reflective prayer so much as an intuitive, inspired response to 'the innermost experience of the Spirit' possible in a variety of circumstances. ${ }^{25}$

The description of the 'Abba! Father!' cry is an important building block in Paul's argument: if none of his addressees had ever called out like this or heard a fellow believer do so, they would have little reason to accept his description of the theological reality of adoption. However, it is significant that Paul takes this cry as evidence of the believers' adoption not only because it represents an appeal to an experiential phenomenon, but also because the Abba cry does not stand alone: it is linked to experience of the Spirit in three ways. First, the reception of the 'Spirit of adoption' enables the Abba cry (8:15); second, 'the same Spirit' witnesses 'with our spirit' (8:16), testifying that the addressees are indeed children of God; third, being a child of God is synonymous with being 'led by the Spirit' $(8: 14)$. According to Paul, the Abba cry is itself a vocal response to the work of the Spirit: outside of the work of the Spirit in their lives, the believers have no reason to cry out to God as their father in such intimate terms. Consequently, it is possible to argue that both the Abba cry and the adoption metaphor which builds on it represent attempts to articulate the impact of experiences of the Spirit in which Paul and his addressees recognised God's action towards them.

These experiences of the Spirit referred to are not described in great detail, but the wider context does offer some clues as to their character. First, 'the same Spirit' ( $\alpha$ v่ò $\tau$ ò $\pi v \varepsilon \tilde{u} \mu \alpha$ ) intercedes with 'wordless

23 Cf. Longenecker, Romans, 705, following C. E. B. Cranfield, A Critical and Exegetical Commentary on the Epistle to the Romans (vol. 1; ICC; Edinburgh: T\&T Clark, 1975), 399.

24 Cf. e.g. David Wenham, Paul: Follower of Jesus or Founder of Christianity? (Grand Rapids: Eerdmans, 1995), 279.

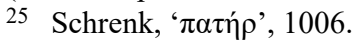




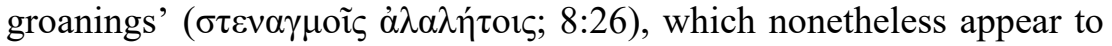
have meaningful, possibly even cognitive, content, as 'God, who searches the heart, knows what is the mind of the Spirit, because the Spirit intercedes for the saints according to the will of God' $(8: 27)$. This suggests that Paul believes the Spirit's intercession can be nonlinguistic and still carry meaningful content. In this sense, the Spirit's 'groanings' are similar to the believers' 'inward groaning' as they await their adoption (8:23): Paul takes this non-linguistic expression ${ }^{26}$ as a meaningful expression of the hope of those who 'have the first fruits of the Spirit' and anticipate the full expression of adoption in the redemption of their bodies (8:23) in the 'sufferings of the present time' (8:18). This opens up the possibility that when Paul refers to the 'witness of the Spirit' $(8: 16)$ he could be referring to a non-linguistic phenomenon that was nonetheless meaningful in a way which 'our Spirit' could perceive.

A second clue points in a similar direction: the Spirit of adoption which the believer receives is opposed to a spirit of 'slavery again to fear' $(8: 15)$. The addition of fear here is a striking interruption to an otherwise straightforward opposition between slavery and sonship. The phrase stands out because Paul does not link fear and slavery in this way anywhere else. ${ }^{27}$ Here, it draws attention to the significant fact that an affective term - a term with emotional or attitudinal resonance - like fear has been inserted into this opposition. Given that Paul associates the Roman's previous states as slaves with a strong and remarkable emotional expression, should we not expect its positive replacement adoption - to have a positive emotional impact? His phrase heightens the emphasis on the recognisable effects of God's action, especially if we consider that Paul expects his addressees to recognise and assent to this description of their own experience. It appears that one of the ways the Romans recognised the effects of God's action in this instance was that it resulted in a removal of fear.

Nor is this the first affective term the Apostle interjects into an otherwise straightforward theological opposition in the chapter. In verse 6, Paul writes: 'To set the mind on the flesh is death, but to set

26 Cf. G. Bertram, ' $\sigma \tau \varepsilon v \alpha \dot{\zeta} \omega$ ' in TDNT 7:600-603.

27 Elsewhere, the terms only occur together in Eph. 6:5, an exhortation to 'slaves' to serve their masters with 'fear and trembling': the thoughts are not comparable. 
the mind on the Spirit is life and peace.' ${ }^{28}$ The addition of 'and peace' is notable because it destroys the strict opposition between 'death' and 'life', indicating it was an important addition for Paul. Whilst it is certainly true that Paul can speak of peace as a forensic, ontological state before God in Romans (e.g. 5:1), the term is employed in the breadth of its meaning across the letter. ${ }^{29}$ For example, in 14:19, peace refers to a communal state of affairs; in 14:17, peace - along with righteousness and joy - is opposed to the physical stuff of food and drink as the present evidence of the kingdom and, as such, can hardly be seen as something without a tangible present effect; in 15:13, Paul prays that his addressees will be filled with 'all joy and peace in believing', clearly referring to the tangible impact of the Spirit on their present emotional state. There are good reasons to see this valence as a part of his intention in Romans 8 as well: the focus of the passage is on the way in which the believers' new theological status in Christ manifests itself in the world; the thought in 8:6 specifically is of 'setting the mind' in a particular direction in daily life; and the term is interjected where it is neither integral to nor taken up in the wider theological argument. At the very least, there is no reason to assume that Paul is employing 'peace' here only to refer to the believer's status before God. In fact, the close link Paul develops between being an adopted child of God and life in the Spirit (8:14) suggests that the relationship between fear and peace should be read in light of the parallel theological oppositions between Spirit and flesh, and life and death. By opposing the peaceable life of the Spirit of adoption to slavery to fear, Paul depicts an affective, this-worldly impact of adoption.

When the Apostle turns his attention to the anticipation of 'the glory about to be revealed to us' in verse 18 , he draws out a further emotional impact of the Romans' experiences of the Spirit, addressing

28 Commentators frequently ignore the interjection, e.g. Longenecker, Romans, 69697; Hultgren, Romans, 300; Käsemann, Romans, 219. Of those who address the interjection, Moo, Romans, 488 and Fitzmyer, Romans, 489 see it as adding nuance to Paul's description of the believer's standing before God; Dunn, Romans, 426 detects a reference to an eschatological state at odds with his interpretation of the passage as a whole; Zeisler, Romans, 209, rightly discerns a claim that the 'Spirit gives a rich quality of life'. Most helpful, though, is Jewett, Romans, 487, who recognises that the interruption is rarely explained and suggests that it serves 'to emphasise the social, relational quality of mind of the Spirit'.

29 As Foerster, 'Eipฑি $v$ ', in TDNT, 2:400-420 recognises: Paul's usage in Romans provides examples for four out of five categories in the NT section (412-15). 
the future object of fear ${ }^{30}$ by referring to its more straightforward opposite, hope ${ }^{31}$ Hope describes the believer's attitude towards events which remain in the future (24), but it is clearly a present state: they were saved in hope (24), which implies a present 'waiting with patience' (25). The believer who has received the Spirit of adoption can wait patiently for their ultimate adoption, the redemption of their body, resting assured in intimate fellowship with their Father, through his Spirit which is active in them, in the present. In this way, and without even referring explicitly to the love of the Father which is implied in the intimacy of the believers' Abba cry and has been 'poured into their hearts' (5:5), Paul draws out a deeply affective impact of adoption: peace and hope combine as a powerful contrast to fear. This suggests that the experiences of the Spirit that Paul links with adoption had an affective impact on their recipients.

A third clue is visible in the way Paul equates being a child of God with being 'led (ö $\gamma o v \tau \alpha$ ) by the Spirit' (8:14). The passive formulation of ó $\gamma \omega$ (to be led) has interesting parallels in 1 Corinthians 12:2 and Galatians 5:18. In 1 Corinthians, Paul refers to pagans being spiritually led astray by idols, but in Galatians the formula denotes the leading of the Spirit which produces fruit. The ecstatic overtones in 1 Corinthians ${ }^{32}$ show this verb can carry enthusiastic connotations, but in Galatians 5 the usage is more nuanced: the keenly felt work of a spiritual force is no less in view than in 1 Corinthians, but the passive exhortation to be led is balanced with a parallel, active exhortation to 'walk' by the Spirit (16). In the description of the struggle between Spirit and flesh with their respective fruits in Galatians 5, human ethical life is described 'in the simple, affective terms of a struggle between competing desires, ${ }^{33}$ which creates space for divine and

30 Cf. Matthew A. Elliott, Faithful Feelings (Grand Rapids: Kregel, 2006), 16-55 on cognitive emotion theory, particularly 33-34 on emotions as having 'objects'.

31 Cf. Elliott, Faithful Feelings, 203: 'Worry, like fear, is the opposite of hope ... Where fear is most often an intense feeling about a specific future event, worry is most often a general pervasive anxiety.' See also the section on hope, 181-92, where Elliott finds a 'definition' of hope in Romans 8.

32 Cf. Anthony C. Thiselton, The First Epistle to the Corinthians: A Commentary on the Greek Text (NIGTC; Grand Rapids: Eerdmans, 2000), 912-14, who sees here a polemic against 'self-induced 'spiritual' experiences' (914; emphasis original).

33 Simeon Zahl, 'The Drama of Agency: Affective Augustinianism and Galatians' in Galatians and Christian Theology: Justification, the Gospel, and Ethics in Paul's Letter, ed. Mark W. Elliott et al. (Grand Rapids: Baker Academic, 2014), 335-52 (336). 
human agency to be seen as complementary rather than competing forces $^{34}$ - the Spirit can and does impact the believers' desires, but the believer must still act. Consequently, Dunn rightly speaks of a 'compulsion', ${ }^{35}$ which should have a noticeable impact on the believers' actions, and, consequently, their lived experience, but which does not simply override all human agency. As Cranfield puts it, 'The daily, hourly putting to death of the schemings and enterprises of the sinful flesh by means of the Spirit is a matter of being led, directed, impelled, controlled by the Spirit. Though the active participation of the Christian is indeed involved ( $(\theta \alpha v \alpha \tau o v \tau \varepsilon)$, it is fundamentally the work of the Spirit, ${ }^{36}$ reshaping believers' desires. ${ }^{37}$ It is important that the body is the site of this encounter, and Paul clearly expects the leading of the Spirit to have a recognisable impact on the Romans'

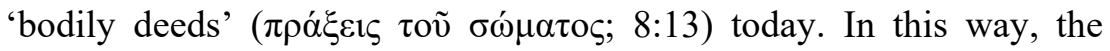
experiences of the Spirit Paul is referring to seem to have produced a particular bodily posture towards some actions and - more importantly for Paul here - away from others.

With these three clues, Paul hints at the possible nature of the experiences of the Spirit which prompt the Abba cry: they point towards a non-linguistic, affective experience which resulted in a reorientation of the body away from specific actions. At this point, it is useful to consider the theoretical plausibility of such a claim. In his book on the emotions, Peter Goldie offers a helpful example:

imagine you are in a zoo, looking at a gorilla grimly loping from right to left in its cage. You are thinking of the gorilla as dangerous, but you do not feel fear, as it seems to be safely behind bars. Then you see that the door to the cage has been left wide open. Just for a moment, though, you fail to put the two thoughts - the gorilla is dangerous, the cage is open together. Then, suddenly, you do put them together: now your way of thinking of the gorilla as dangerous is new; now it is dangerous in an emotionally relevant way to you ... Now, in feeling fear towards the gorilla you are emotionally engaged with the world, and, typically, you

\footnotetext{
34 The point here is that the contrast between divine and human agency need not be seen as a 'zero-sum game'.

35 Both in his commentaries on The Epistle to the Galatians (London: A. C. Black, 1993), 300, and on Romans, 450.

36 Cranfield, Romans, 1:395.

37 Cf. John M. G. Barclay, Paul and the Gift (Grand Rapids: Eerdmans, 2015), 504508 where he draws on Bourdieu's concept of an embodied habitus 'inscribed in all manner of bodily habits and expectations' to illuminate the contrast between death and life developed in Rom. 5-8.
} 
are poised for action in a new way - poised for action out of the emotion. ${ }^{38}$

In this example, the new state of affairs is reported in the same terms as the old (the gorilla is dangerous and the gate is open), but the understanding is now different and deeper. Moreover, the deeper understanding was achieved by feeling fear. On this account, the feeling of fear is not an 'add-on', separable from a discursive understanding; rather, thinking of the gorilla with the feeling of fear means thinking of the gorilla in a new way and being prepared to act accordingly. ${ }^{39}$ As Mark Wynn observes, 'Goldie is describing how an initial conceptually articulated, affectively neutral kind of understanding may be carried further by feeling ... [how] feeling can extend the understanding achieved in discursive thought.' 40

This model offers one way of understanding how felt experiences of the Spirit could enhance the believers' understanding of God as Father: an initial understanding could be deepened by becoming emotionally relevant in a new way through their impact. Certainly, the description

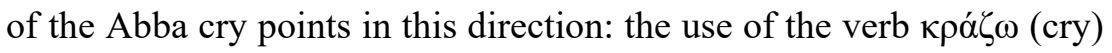
suggests Paul is referring to an utterance associated with deeply felt prayer, and the use of the Aramaic appellation Abba connotes a striking level of intimacy which intensifies a devotional understanding of God as Father available more broadly across the NT. It is also possible to suggest that outside of such an experience this understanding could not be fully accounted for: it is perhaps, as Wynn puts it, 'the sort of understanding that can only be realised in feeling'. ${ }^{41}$

If the Abba cry gave expression to intuitively grasped content made available in deeply felt experiences of the Spirit which enhanced the believers' understanding of God, it did so as an unreflective, emotional outburst. On the other hand, the adoption metaphor is somewhat different: it represents a reflective attempt to adequately express the content of the spiritual experiences which inspired the Abba cry. As such, an examination of this metaphor can shed further light on the way

38 Peter Goldie, The Emotions: A Philosophical Exploration (Oxford: Oxford University Press, 2000), 61.

39 Cf. Mark Wynn, Emotional Experience and Religious Understanding: Integrating Perception, Conception and Feeling (Cambridge: Cambridge University Press, 2005), 130-32 on the 'body's readiness for action' (131) in Jonathan Edwards, as a part of RE.

40 Wynn, Emotional Experience, 99, 128. Emphasis added.

41 Wynn, Emotional Experience, 99. 
RE informed the development of Paul's thought. Because the language of adoption is very unusual in the NT, restricted to five occurrences in the Pauline literature, ${ }^{42}$ its theological meaning and background has attracted a good amount of scholarly scrutiny, ${ }^{43}$ though less attention has been paid to its significance for the lived religion of the addressees, mirroring broader trends in NT studies. ${ }^{44}$ However, Erin Heim's recent study has used metaphor theory to examine the ways in which the language of adoption may have shaped the perception and emotion of Paul's addressees, ${ }^{45}$ and with this focus she has helpfully begun to explore its religious significance. ${ }^{46}$ As Heim rightly notes, Paul's adoption metaphor draws on two sources - a scriptural concept of divine sonship, and Greco-Roman socio-legal terminology. ${ }^{47} \mathrm{I}$ will address salient elements of these two models briefly in turn before considering ways in which this language might have been shaped by RE.

In Romans 9:4-5 Paul lists adoption among the benefits which

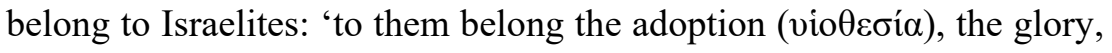

42 Rom. 8:15, 23; 9:4; Gal. 4:6; Eph. 1:4.

43 For a recent overview, see Erin M. Heim, 'Light Through a Prism: New Avenues of Inquiry for the Pauline vio $\theta \varepsilon \sigma i \alpha$ metaphors' (Ph.D. dissertation, University of Otago, Dunedin, 2014), 2-14. This thesis has now been published as Adoption in Galatians and Romans: Contemporary Metaphor Theories and the Pauline Huiothesia Metaphors (Leiden: Brill, 2017), but I have not had access to this version. Also important are Michael Peppard, The Son of God in the Roman World: Divine Sonship in Its Social and Political Context (New York: Oxford University Press, 2011); Trevor J. Burke, Adopted into God's Family: Exploring a Pauline Metaphor (NSBT 22; Nottingham: Apollos, 2006); James M. Scott, Adoption As Sons of God: An Exegetical Investigation into the Background of YIO@EIIA in the Pauline Corpus (WUNT 2.48; Tübingen: Mohr Siebeck, 1992); and Brendan Byrne, 'Sons of God - Seed of Abraham': A Study of the Idea of the Sonship of God of All Christians in Paul against the Jewish Background (AnBib 83; Rome: Pontificio Instituto Biblico, 1979). Cf. also the recent articles of Richard N. Longenecker, 'The Metaphor of Adoption in Paul's Letters', The Covenant Quarterly 72 (2014), 71-78 and Kyu Seop Kim, 'Another Look at Adoption in Romans 8:15 in Light of Roman Social Practices and Legal Rules', Biblical Theology Bulletin 44 (2014), 133-43 not engaged in Heim's thesis.

44 Cf. Hurtado, 'Experience and Innovation'; Mark Batluck, 'Religious Experience in New Testament Research', Currents in Biblical Research 9 (2010), 339-63 (354); Roland Deines and Mark Wreford, 'Introduction' in ed. Roland Deines and Mark Wreford, Epiphanies of the Divine (Tübingen: Mohr Siebeck, forthcoming).

45 Heim, 'Light Through a Prism'.

46 Although I share Heim's focus, my approach can offer greater precision regarding the relationship between the language of adoption and any underlying RE as they developed in Paul's thought: at points, Heim is unclear whether the metaphor 'draws on' experiences of the Spirit, or 'creates' or 'structures' these experiences (see e.g. 'Light Through a Prism', 240).

47 Heim, 'Light Through a Prism', 103-37 
the covenants, the giving of the law, the worship, and the promises; to them belong the patriarchs, and from them, according to the flesh, comes the Messiah, who is over all, God blessed forever'. This clearly situates adoption within a scriptural framework, ${ }^{48}$ but the complete absence of the term and its cognates in the LXX, combined with the lack of functionally equivalent terminology in Hebrew, makes it difficult to identify specific co-texts for this metaphor in the OT. ${ }^{49}$ To understand the scriptural context of the adoption metaphor, it is more helpful to consider its obvious reliance on a prior understanding of God as Father. A widespread designation in the NT, this usage is present in the Hebrew Bible, although it is comparatively rare. In God of the Living, Feldmeier and Spieckermann trace diachronically the employment of 'father' as a name for God, arguing that 'the few passages in the Old Testament that speak of the Father are far from marginal' ${ }^{50}$ On their account, God was initially designated father to denote the closeness of relationship between God and a newly enthroned Davidide (e.g. Ps. 2; cf. 2 Sam. 7:14). In the aftermath of exile and the destruction of the Davidic line, however, God's fatherhood was re-imagined for his people as a whole: it found a place in lament and prophetic promise and came to represent an 'insistence on God's saving attention in the midst of the experience of God's distance' ${ }^{51}$ Further, in late texts like Tobit 13, Sirach 51:1-12, and Sapientia 1-5, naming God in this way even began to imply 'a new experience of God's proximity', emphasising his saving action. ${ }^{52}$ Thus, the Father salutation asserts that God is present and attentive to save his children, even when faced with the experience of his apparent absence. ${ }^{53} \mathrm{~A}$ similar emphasis is present in the language of adoption, in which Burke sees an 'organizing metaphor for the doctrine of

48 This is the key insight of Byrne, 'Sons of God'.

49 Cf. Scott, Adoption, 3-60 and Heim, 'Light Through a Prism', 108-13 on the terminology of adoption and its absence in the OT: this is precisely the reason Scott attempts to locate Paul's usage exclusively in 2 Sam. 7:14 as a Hebrew 'adoption formula' but this suggestion has not proved persuasive; cf. the critiques of Heim, 'Light Through a Prism', 118-21 and Burke, Adopted, 70-71.

50 Feldmeier and Spieckermann, God of the Living, 53.

51 E.g. Psalm 89; 103; Isaiah 9:1-6; 63:7-64:11. Cf. Feldmeier and Spieckermann, God of the Living, 57-65.

52 Feldmeier and Spieckermann, God of the Living, 65.

53 With the prophetic promise, this tradition remains open to the possibility of God's radical presence to a son in a new way (Isa. 9:1-6), and this promise is taken up and applied to Christ (Matt. 4:12-17; Luke 1:76-79). 
salvation', integrating the saving work of Christ for the believer, demanding an ethical response, and expressing the eschatological tension characteristic of Paul's soteriological thought. ${ }^{54}$

Whilst the adoption metaphor is clearly at home within this scriptural framework, the term itself is appropriated from GrecoRoman legal discourse. ${ }^{55}$ Adoption is well attested in epigraphical sources, and in both Greek and Roman contexts its primary intent was to 'provide an heir to take over the estate, to pass along an inheritance, and to secure care for an adoptive father in his old age'. ${ }^{56}$ Although Seneca the Elder emphasises the importance of prudence on the part of the adoptee and even considers the possibility of making 'a prey of childless old men',57 Heim rightly concludes that 'the purpose of adoption was to secure a suitable heir to take over the father's name and estate' ${ }^{58}$ This was particularly the case in the most prominent instances of adoption, namely the Roman imperial family, where succession and the transfer of power were also at stake.

Both the scriptural framework of divine sonship and the GrecoRoman socio-legal institution of adoption emphasise the action of the Father: in the former, God the Father disciplines and shows mercy, with the ultimate aim of saving his children; in the latter, the paterfamilias chooses a suitable heir to establish his family and secure his own future. However, in both models, the worthiness of the (prospective) child is also assumed. On the one hand, post-exilic OT texts name God 'Father' to 'direct bitter charges against God' (e.g. Psalm 89) $)^{59}$ and motivate him to action on the basis of an existing relationship: they assume that God is already in relationship with his children, with the consequence that he can be expected to act on their behalf and, consequently, be rebuked for not doing so. On the other hand, strangers and 'slaves' (8:15) were rarely adopted under Roman

\footnotetext{
54 Burke, Adopted, 41-44.

55 For overviews of the relevant material cf. Lene Rubinstein et al., 'Adoption in Hellenistic and Roman Athens', Classica et Mediaevalia 42 (1991), 139-51, and Emiel Eyben, 'Fathers and Sons', in Marriage, Divorce, and Children in Ancient Rome, ed. Beryl Rawson (New York: Oxford University Press, 1991), 106-43.

56 Heim, 'Light Through a Prism', 127. Cf. Peppard, The Son of God, 59: '[adoption] was not enacted to stabilize the life of a child, but to stabilize the future of a father ... Roman adoption, as with most other Roman family relations, was unusually focused on the paterfamilias.'

57 Controversiae, 1.6.6.

58 Heim, 'Light Through a Prism', 136. Emphasis added.

59 Feldmeier and Spieckermann, God of the Living, 59.
} 
law because they were not appropriate heirs: heirs were normally selected from families of similar social standing. ${ }^{60}$ In this context Kim rightly points out that 'God's adoption was an act of love'61 which subverts these expectations: in Romans 8, adoption is presented as an expression of God's Fatherly mercy in establishing the unworthy (5:8) as his children and heirs alongside Christ (8:16-17). Indeed, the presence of Christ as a natural heir strengthens the emphasis on the incongruity of the grace shown towards the Romans: though Christ is unique as God's 'own Son' (Rom. 8:1), he does not consider equality with believers ${ }^{62}$ something to be shunned, but is willing to share his honoured status with them as co-heirs (Rom. 8:17) of the same father. In this way, adoption is presented as a loving choice on the part of both Father and Son. Thus, the adoption metaphor itself draws on scriptural and cultural elements to emphasise God's loving salvific action to establish intimate relationship with unworthy recipients by becoming present to them through the Spirit of adoption in noticeable ways.

In her discussion of Romans 8, Heim argues that the language of adoption 'provides quite a specific and unique description' of God's establishment of relationship with the Romans; she presents it as an 'emphatic' metaphor, noting that 'a metaphor is emphatic to the degree that it will not brook the substitution of another word or words'. ${ }^{63}$ Because the Romans have received the Spirit of adoption, they now exist as children of God who are led by the Spirit (8:14), and are coheirs with Christ of God's promises (8:17), eagerly awaiting the ultimate fulfilment of these promises (8:23). Paul clearly found this form of words particularly fitting to what he was attempting to express, and expected his audience to recognise a similar fit between his words and their experience. This suggests that when the Romans encountered the Spirit of adoption, they experienced 'the incongruity of grace ... [which] rendered human lives in tune with the Spirit of God' ${ }^{64}$ The non-linguistic, affective impact of the Spirit which orientated their bodies towards a new life $(6: 12-13)$ in Christ was a radical personal

60 Cf. Christiane Kunst, Römische Adoption: Zur Strategie einer Familienorganisation (Hennef: Marthe Clauss, 2005), 294, who argues that adoption was rarely a tool for social mobility.

61 Kim, 'Another Look', 141.

62 Under both Greek and Roman law, adopted sons had the same rights as natural sons (cf. Heim, 'Light Through a Prism', 128-29, 133-34).

63 Heim, 'Light Through a Prism,' 213.

64 Barclay, Paul and the Gift, 503. 
encounter with the grace of God which saved the unworthy $(8: 1-2){ }^{65}$ This deepened an available understanding of God as Father, prompting the believers to appropriate Christ's intimate relationship with God for themselves in moments of deeply felt prayer. In this way, a particularly powerful and significant RE left a lasting legacy in Paul's choice of the language of adoption to describe a theological reality.

\section{Defining Religious Experience}

In conclusion, I would like to return to the problem of defining RE. In this paper, I have followed Luz in using theological categories to focus the discussion. This is a useful approach, not least because it addresses concerns that 'religious experience' might be something nebulous, vague, or imprecise, more a projection of human religion than response to divine revelation. However, as Martin Hengel writes, 'we cannot talk theologically of God's disclosure of himself in Jesus and the apostolic testimony without at the same time grasping the form and content of this communication by means of historical research'. ${ }^{66}$

In Romans 8, I have argued that Paul's language of adoption can be seen as a particularly fitting attempt to articulate deeply felt experiences of grace which developed the recipients' understanding of what it meant for God to be their Father. Paul's apparent willingness to draw on the noticeable effects of God's action to shape his account of theological reality problematises concerns like Burke's that the Spirit's witness ought to be 'reiterative rather than innovative'. ${ }^{67}$ Burke himself notes that 'the Holy Spirit plays a critical role in assuring adopted sons of their new filial disposition', but immediately qualifies this: 'this is no mystical experience, as though the Spirit subjectively whispers to us "You are God's son"". ${ }^{68}$ This is an excellent example of the tendency to downplay the significance of subjective experience in NT, which owes more to 'the definitive conclusion [of dialectical theology] that

65 Cf. Barclay, Paul and the Gift, 504-19. See also Michael J. Gorman, Apostle of the Crucified Lord: A Theological Introduction to Paul and His Letters (2nd ed., Grand Rapids: Eerdmans, 2016), 111 for the distinction between 'personal' and 'private', which informs my argument here: the impact of the Gospel is never less than personal, but always more than private.

66 Martin Hengel, Acts and the History of Earliest Christianity, trans. John Bowden (Philadelphia: Fortress, 1979), 136.

67 Burke, Adopted, 150 (italics original).

68 Burke, Adopted, 150. 
Christian faith was not a religion, but rather the end of all human religion' ${ }^{69}$ than to Paul. The result is that Burke's depiction of what is happening in verse 16 becomes rather unclear. He speaks of the Spirit 'strik[ing] a chord with the human spirit of the adopted son' and 'mak[ing] us aware of our adoption' having ruled out the possibility of any 'subjective' communication. Whilst this portrayal is theologically unobjectionable, it leaves unanswered the question of how the Spirit can assure the believer of their new status without addressing them in their subjectivity. ${ }^{70}$ It also reduces the scope of adoption to its bare theological bones: 'God's Spirit is sent into our hearts to let us know we are his adopted sons ${ }^{71}$ so that doubt might be avoided, Burke writes. Here, the theological significance of adoption has unhelpfully obscured the role experiences of the Spirit played in communicating this new reality. This account of the Spirit's reassuring role has been diluted and become so vague as to be inadequate: the Spirit no longer witnesses with the believer's Spirit bearing the thick, affective fruit of peace and hope, but provides a thin sense of theological certainty. Paul has no such reservations, using the intentionality of his and his addressees' experiences of the Spirit as the basis of his argument.

69 Luz, 'Paul as Mystic', 131. Here Luz is referring to the attitude that led the young Barth to rebuke Harnack by claiming that "so-called "religious experience" is as different from the awakening of faith by God as earth is from heaven' ('Fifteen Answers to Professor von Harnack' in The Beginnings of Dialectic Theology, ed. James M. Robinson (vol. 1; Richmond: John Knox, 1968), 167). Johnson, Religious Experience, 12-13 shares Luz's concerns, but critiques historical-critical study more specifically.

70 Schreiner's (Romans, 427) account is equally vague: 'the text describes a religious experience that is ineffable, for the witness of the Holy Spirit with the human spirit that one is a child of God is mystical in the best sense of the word ... [providing] a certainty in the heart that transcends human comprehension'. Whilst he rightly recognises the non-linguistic character of the experience, he insists that it must remain non-linguistic - despite the fact that this 'ineffable' experience has been expressed in both the Abba cry and in Paul's description of adoption. However, cf. Janet Martin Soskice's (Metaphor and Religious Language (Oxford: Clarendon, 1985), 160) argument that the New Testament 'both records the experiences of the past and provides the descriptive language by which any new experience may be interpreted. If this is so, then experience, customarily regarded as the foundation of natural theology, is also the touchstone of the revealed. All the metaphors which we use to speak of God arise from experiences of that which cannot be adequately described.' The fact that the significance of a revelatory experience can never be fully articulated need not undermine the claim that it can come into language: the incarnation itself argues in this direction.

71 Burke, Adopted, 150. 
The tendency to neglect religious questions in favour of theological themes has been widespread within NT studies and has attracted criticism from the likes of Luke Timothy Johnson ${ }^{72}$ and Larry Hurtado, ${ }^{73}$ though the recent contributions of the SBL Section for Religious Experience in Early Judaism and Early Christianity ${ }^{74}$ suggest that RE has gained attention more recently. On the other hand, Mark Batluck's recent literature review rightly concludes that an inductive definition of RE - a definition worked out on the basis of the texts themselves - remains a desideratum. ${ }^{75}$ The fact that this is still the case is problematic because without their own definition, NT scholars have tended to draw on others provided by religious studies to approach the text. ${ }^{76}$ These definitions often reflect distinctly modern presuppositions and consequently apply an anachronistic conceptual framework to the NT, obscuring, as well as illuminating, elements of the text. ${ }^{77}$

To this end, it is helpful to consider what distinguishes the experiences of the Spirit which gave rise to the adoption metaphor. There are three things.

In the first instance, they are related to God. At a more general level, the NT includes references to an impressive plethora of Spiritual realities which humans can encounter in different ways - the devil,

72 Johnson critiques what he sees as the Protestant proclivity to consider 'theology' at the expense of 'religion' in Religious Experience, offering an alternative, corrective approach (chs 1 and 2), which he applies to baptism (ch. 3), glossolalia (ch. 4), and the Lord's Supper (ch. 5).

73 Most salient is Hurtado's seminal article 'Experience and Innovation', which argues that RE underpins early Christian religious innovation including the worship of Christ. More recently, Hurtado has revisited similar themes in another article: 'Revelatory Experiences and Religious Innovation in Earliest Christianity', Expository Times 125 (2014), 469-82.

74 Experientia I: Inquiry for Religious Experience in Early Judaism and Christianity, ed. Frances Flannery, Colleen Shantz, and Rodney A. Werline (Atlanta: SBL, 2008); Experientia II: Linking Text and Experience, eds Colleen Shantz and Rodney A. Werline (Atlanta: SBL, 2012); especially relevant is the section on Paul in Experientia $I$, which includes Troels Engberg-Pedersen, 'The Construction of Religious Experience in Paul', 147-57.

75 Batluck, 'Religious Experience, 354.

76 E.g. Hurtado, 'Experience and Innovation' and 'Revelatory Experiences' both draw on frameworks derived from the research of Rodney Stark (e.g. 'A Taxonomy of Religious Experience', Journal for the Scientific Study of Religion 5 (1965): 97-116), among others.

77 E.g. Johnson, Religious Experience, 60-64 relies on a definition derived from Joachim Wach, a professor of Religious Studies in the Jamesian tradition, which refers to 'ultimate reality', neglecting encounters with other spiritual realities like angels and demons. 
angels, demons etc. ${ }^{78}$ What unites these realities is that they are all conceived of as 'trans-empirical': they are recognisable and communicable, but somehow obviously different from the phenomena of everyday experience.

Second, these experiences were deeply felt and had a holistic, affective impact on the believers: they were not a matter of cognitive assent to propositional truths, but a life-changing Christ-centrification of emotions, thought patterns, words, and actions.

Third, despite being theologically an expression of realised eschatology, these experiences remained for the believers on the level of their everyday experiences, happening here and now, and deepening an already existing understanding. Their encounters with the Spirit happened in 'the real world' and interacted with an existing worldview - even as they could contribute to new theological understanding, possibly in revolutionary and innovative ways.

With these points in mind, my suggestion is that we can usefully describe RE as the felt impact of trans-empirical elements within the culturally patterned life of an individual or group. Such a definition should be sufficient to function heuristically 'as a means of pointing to the sort of reality we mean'. ${ }^{79}$

In his essay on Paul's mysticism, Luz makes the point that 'Mystical-sounding expressions in Paul occur ... when he interprets the experience of the Spirit which is given to believers.' ${ }^{80}$ Paul's exploration of adoption showcases this excellently: on the basis of deeply felt encounters with the Spirit common to the Apostle and his addressees, he developed a normative theological interpretation. On the other hand, Luz rightly strikes a note of caution: "The Lord is the Spirit" (1 Cor. $6: 17 ; 15: 45 ; 2$ Cor. 3:17), but at the same time the Lord is more than the spiritual experiences which the Spirit brings about. ${ }^{81}$ Nonetheless, if Schweizer is right that the Spirit was a fact of experience before it became a theme of doctrine, something similar can

78 Cf. e.g. Guy Williams, The Spirit World in the Letters of Paul the Apostle: A Critical Examination of the Role of Spiritual Beings in the Authentic Pauline Epistles (Göttingen: Vandenhoeck und Ruprecht, 2009), and Clint Tibbs, Religious Experience of the Pneuma: Communication with the Spirit World in 1 Corinthians 12 and 14, (WUNT 2.230; Tübingen: Mohr Siebeck, 2007).

79 Johnson, Religious Experience, 60.

80 Luz, 'Paul as Mystic', 136.

81 Luz, 'Paul as Mystic', 136. 
perhaps be said of adoption. This possibility must at least be taken into account by those who would understand Paul rightly. 